\title{
Liturgy and non-colonial thinking: Speaking to and about God beyond ideology, religion and identity politics - Towards non-religion and a unbearable freedom in Christ
}

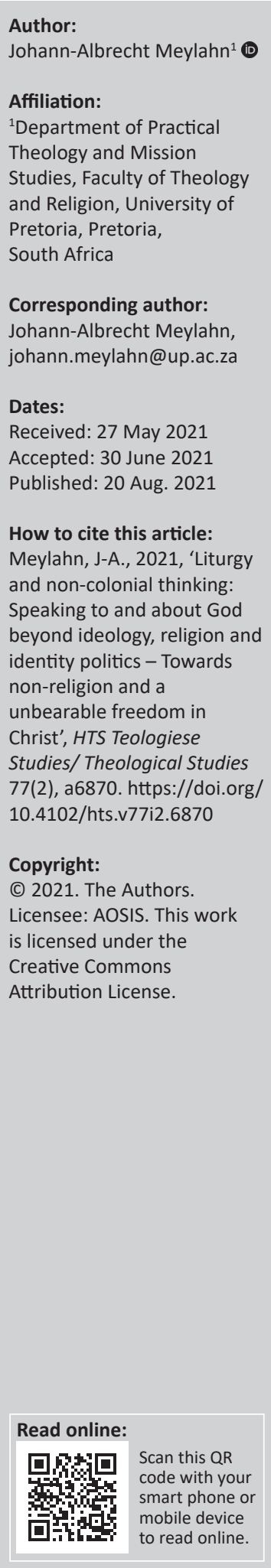

It has been argued that most countries that had been exposed to European colonialism have inherited a Western Christianity thanks to the mission societies from Europe and North America. In such colonial and post-colonial (countries where the political administration is no longer in European hands, but the effects of colonialism are still in place) contexts, together with Western contexts facing the ever-growing impact of migrants coming from the previous colonies, there is a need to reflect on the possibility of what a non-colonial liturgy, rather than a decolonial or postcolonial liturgy, would look like. For many, postcolonial or decolonial liturgies are those that specifically create spaces for the voice of a particular identified other. The other is identified and categorised as a particular voice from the margins, or a specific voice from the borders, or the voices of particular identified previously silenced voices from, for example, the indigenous backyards. A question that this context raises is as follows: Is consciously creating such social justice spaces - that is determined spaces by identifying particular voices that someone or a specific group decides to need to be heard and even making these particular voiceless (previously voiceless) voices central to any worship experience really that different to the colonial liturgies of the past? To give voice to another voice, is maybe only a change of voice, which certainly has tremendous historical value, but is it truly a transformation? Such a determined ethical space is certainly a step towards greater multiculturalism and can therefore be interpreted as a celebration of greater diversity and inclusivity in the dominant ontology. Yet, this ontology remains policed, either by the statemaintaining police or by the moral (social justice) police.

Contribution: In this article, a non-colonial liturgy will be sought that goes beyond the binary of the dominant voice and the voice of the other, as the voice of the other too often becomes the voice of a particular identified and thus determined victim - in other words, beyond the binary of master and slave, perpetrator and victim, good and evil, and justice and injustice, as these binaries hardly ever bring about transformation, but only a change in the face of master and the face of the slave, yet remaining in the same policed ontology.

Keywords: liturgy; homiletics; decolonial; postcolonial; non-colonial.

\section{Liturgy and decolonial thinking}

The moment one puts liturgy together with colonialism and/or decolonial thinking or with the idea of developing post-colonial liturgies (see Carvalhaes 2015), one has entered the realm of social justice often confused with the ethical space ${ }^{1}$ (see Ruda 2011). Ethical space can be interpreted as the space from which an indeterminate [Call] (see Meylahn 2021) emerges, calling to respond and into ethical responsibility but prior to any determinations, and only in the ethical or moral response is the Other determined as a specific identifiable other, who is then identified as marginal, as part of a determined oppressed class or an ostracised identity, or as living a border existence in the realm of the dominant Same. If this move places liturgy in the vicinity of the ethical space, which is then interpreted as a social justice space, the question is raised, if one can bring liturgy into the realm

1.I am specifically referring to Frank Ruda's use of the concept of ethical space in his interpretation of both Hegel and Marx. "The rabble therefore seems to fill the ethical space of the state in a peculiar way - as matter for Hegel fundamentally fills space' (Ruda 2011:95). 'The rabble as the matter of ethicality is both: an effect and also the logical a priori of the ethical space. He only emerges in the process of determination and as an effect of determination ("after") the ethical and as soon as it emerges it brings with it the insight that it will always have been a part of every element of ethical space ("before")' (Ruda 2011:96). 'The problem that poses itself here is that this peculiar matter has to be without determinations, and must constitute the ethical space as absolute void but without being dialectically determined as indeterminate or not yet determined matter. If the rabble thus has no existence anymore, this also means that its inorganic presence is bodiless and does not have any appearance proper to him' (Ruda 2011:96). 'But as the rabble as matter of the ethical space remains forever in this implicit dimension; there is no direct access to the rabble, no knowledge about his existence' (Ruda 2011:120). 'If the rabble is on one side the matter of the ethical space, the matter in and for itself, can this matter without form, without determination, be understood as a set, as multiplicity without unity?' (Ruda 2011:150-151). 
of ethics and subsequently morality or is it not always already within that realm? Meyer-Blanck (2015) argues that one of the main functions of liturgy (he is specifically referring to mainline churches of particularly Europe - Germany) is to be a moral agent within society. His argument is based on the idea that the liturgy (divine service) is a public performance of the Christian religious system² (Meyer-Blanck 2015:2). This public performance acts as a moral agent within society, not only for the participants of the liturgy, but also for the greater general public. The general public is often indirectly addressed by this public performance, as even those who do not attend the service, know and often take comfort in the idea that there are divine services in various churches, and therefore, they believe a moral agency to be at work within society and thereby morality is upheld. Most people are thankful for these mainline religious institutions within society because of this moral role these institutionalised religions play within society, even if they (the people) do not actively participate in these liturgies and rituals. This social function of religion was already highlighted in Émile Durkheim's (see Munn 1973) view of religion and his understanding of religion as a social phenomenon and thus a social fact. He specifically focussed on the social function of ritual. Likewise, Marcel Mauss interpreted religion as a 'total social phenomenon' (see Bell 1997:26). Nancy Munn (1973), in reference to Durkheim, interprets ritual or social symbolism as the switch point between the external moral constraints and groupings of the socio-political order, and the internal feelings and imaginative concepts of the individual actor.

The moment that one speaks to the divine in prayer or any other ritual, or believes oneself to be the messenger of a divine message within the context of a religious community, one is participating in the creation of a certain worldview, keeping in mind Freud's critique of the worldviews. ${ }^{3}$ Important to note is that these worldviews are created by human desire (wish) according to Freud. The speaking of language, in response to this wish, is a speaking that carries out a fourfold, according to Heidegger (1971:179). For Heidegger, in the creation (calling into being) of a world, which happens through the speaking of language (Heidegger 1971:190f), there is always a divine element as part of the fourfold. It is therefore clear that religion, specifically in its ritual form (including Christian liturgy), plays an important role in the moral structuring of society by clearly identifying and then proclaiming the divine and by implication the good (good moral citizenship), which then also allows the religions to identify and condemn what is evil and wrong. The speaking of a particular language carries out a specific world in line with a certain wish and thus the construction of a

2.Die Liturgie der Kirche ist die öffentlich performative Gestalt des christlichen Religionssystems. Als solche ist sie selbstverständlich auch eine Moral-Agentur der Gesellschaft. Der Öffentlichkeitscharakter der Liturgie impliziert die gesellschaftliche Verantwortung und damit auch die Spannungsfelder von 'gut und böse', 'human und inhuman', 'lebensförderlich und lebensgefährdend'. Die Liturgie wird in diesem Sinne mindestens von den Rezipienten moralisch interpretiert.

3.In my opinion, then, a Weltanschauung is an intellectual construction, which solves all the problems of our existence uniformly on the basis of one overriding hypothesis, which, accordingly, leaves no question unanswered and in which everything that interests us finds its fixed place. It will easily be understood that the possession of a Weltanschauung of this kind is amongst the ideal wishes of human possession of a Weltanschac worldview (which always includes a view of what the good is and its opposite: the evil).

In a particular world, there is seldom just one set of moral values, but often more than one, and sometimes conflicting and antagonistic sets of values. One could probably argue that for most worldviews there are at least two sets of values that are dominant, and thereby divide that specific world into two main camps: those with us and those against us (same and other). This could be broken down into those who support the ideal version of the dominant worldview and those who believe themselves to be called to prophetically challenge the reality of the dominant worldview and offer a 'heavenly' corrective or alternative (or kingdom alternative), which could be interpreted as a more just or more morally [politically] correct alternative. Although the prophetic (revolutionary) alternative might not be that different to the ideal version of the dominant ethic of the dominant ideology, it focuses on the moral or social justice shortcomings of the dominant worldview. In this sense, the prophetic is related and maybe even bound to the ethical space - where the shortcomings and failures of any system are. The poor, marginalised, ostracised, oppressed of any system are the necessary condition for this ethical space as they are indicators of the failure of the system. The prophetic, by being related to the ethical space, is tempted to colonise this space by clearly identifying, classifying and determining this space and thereby populating it with identities. The temptation is to give particular determination to the indeterminant matter of ethical space, and thereby to colonise the ethical space. The prophets and those who believe themselves to be fighting for social justice are called into responsibility by the ethical space. But in their response, it is possible for them to colonise this space by stratifying, naming, identifying and classifying the different voices of this space and thereby transform the latent double universalism of the rabble or the universalism of the proletariat into a specific historic class or specific political identities which form the basis of identity politics. There is a fine line between the universal ethical and revolutionary agency of the proletariat (rabble) and the particular determined class or racial or sexual identity. The one has the agency to transform the world and even transform the laws of change (Ruda 2011:174) and the other only makes a few shifts in the dominant ontology, without transforming the system.

The prophetic has an important role to play, with its proximity to the ethical space and the responsibility to that space. But it is continually confronted with a great temptation of both determining the indeterminate space and constructing their own interpretation of the good and thereby fulfilling the ideal wish by constructing a worldview where everything that interest them finds a fixed place (see Freud 1964:158).

These two approaches to the 'good' are also clearly discerned in the Kairos Document (The Kairos Theologians 1985:9ff.), where two dominant types of theology are identified, and 
therefore, one could also say two churches: namely the state theology (state church) - public presentation through communication (communicative presentation ${ }^{4}$ ), a public state morality of 'good' citizenship, and on the other hand prophetic theology (prophetic church) (The Kairos Theologians 1985:23ff.) - public presentation through communication, a social justice corrective as an alternative good. These two, state religion (ideology / theology) and prophetic religion (ideology / theology), might actually share the same interpretation of the good, but they have very different interpretations of who is all included in this good and how this good is achieved, thereby differing in their interpretation of the fixed places for that which interests them. For example, in South Africa under apartheid the state religion (ideology) wanted the good life and the good for a select few (white Afrikaner nationalists who are also good Calvinist) with the exclusion of the vast majority, while the prophetic religion (ideology) wanted a more inclusive good for 'all' irrespective of race, sex, and religion. But they more or less agreed as to what the good is: a specific interest and interpretation of freedom, which is then universalised in a just and good state. For the one, the good was exclusive (whites only), and for the other, it was more inclusive. The prophetic religion or ideology is not necessarily opposed in principle to the dominant ideology (worldview) or ruling ideology but highlights the 'injustice' within the dominant world, with the desire to open this world to include the specifically identified other (identified minorities and/or majorities, etc.). The prophetic voice focuses on, for example, the poor, the outcast, the marginal, the migrant and the various forms of border existence within the dominant world, as well as the believed original indigenous voice of the land, in those contexts where land was stolen from the indigenous people. This is also how some interpret the call and the challenge of decolonial thinking - to focus on these border (marginal) existences and voices (see Mignolo 2011; Wyller 2018). Grosfoguel (2009:26) unpacks what border thinking is: 'Border thinking is not an anti-modern fundamentalism; it is a decolonial transmodern response of the subaltern to Eurocentric modernity'.

Carvalhaes (2015), in his introduction, argues for finding unknown forms of life, indigenous resources and resistant processes in the porous spaces of the dominant ideology or dominant religion. These are various responses to the ethical space, and thus, they have identified the right places of the call of the ethical space: the poor (broadly understood) are the necessary condition of the emergence of the rabble, as the poor are the necessary condition of the proletariat (Ruda 2011:116) who are the universal agents of change. The question is how to respond to the call of the ethical space that calls into ethical responsibility? The contingent attitude of indignation is necessary for the poor to become the rabble (see Ruda 2011). Yet, the response cannot be to identify or determine the victim, as then the scapegoat mechanism returns (Girard 1987), but to expose the scapegoat mechanism (Girard 1987:166) that structurally creates victims.

4.This is my translation of Schleiermacher's idea of mitteilende Darstellung (Schleiermacher 1850:75).
The state church acts as the moral guardian and teacher of the dominant morality of state ideology and its particular view of a good citizen of the state, which is generally accepted as the kind of citizens that serves the general good of all and for all people. For example, in the Western world the dominant good is seen in certain fixed interests as to how being liberal, open and hospitable and being democratic are to be interpreted. Likewise, there are fixed ideas as to how values such as tolerance, pluralism and freedom are to be interpreted within the context of a certain interpretation of a free market to ensure these ideas of freedom and diversity. This system, like all systems, has its poor (victims), and therefore, to protect the ideas of freedom for all, there needs to be a social conscience and the need to look after the vulnerable via the diaconal arms of the church and state, as well as the various NGOs tasked with caring for the most vulnerable within society. The social conscience translates into the necessary care for those who fall through the cracks of a crumbling neo-liberal system. The prophetic church, or those who have given themselves the task of being the voice of the voiceless, the specifically identified voice of the Other, also act as moral agents, or at least they see themselves as the ethical agent by being the champion of the Other (marginal, exploited, dispossessed, indigenous, voiceless, etc.), in other words, their particular construct or determination of who the poor are. The prophetic church speaks for the poor, and often believes itself to be speaking with the poor, the poor who will always be amongst you (Jn 12:8 or Mt 26:11 or Dt 15:11).

Thomas Lynch (2014:212) argues that although this prophetic liberation theological voice is important, 'they leave intact an underlying theological discourse which is inclined to reinstitute forms of oppression - it is a dependent form of resistance'. Or as Alistair Kee (1990:ix) argues, liberation theology's theology, or in this article, prophetic public theology's theology, is a no-go area. Jacques Rancière (2003) wrote about this idea of the 'poor' and how they have been constructed by philosophers, intellectuals to then be used as an ethical tool. Laruelle (2015) unpacks this in the context of his idea of the determined intellectual. ${ }^{5}$ The poor (including all its various variations) will always be there. 'What becomes clear here is that out of the internal dynamic of civil society there is an unavoidable production of poor or impoverished masses' (Ruda 2011:12). Therefore, the poor are a structural necessity for any ideological (religious-ethical) system or construction of civil society. The poor, which will always be amongst you, are a structural product of any social system, but likewise they will be used as a necessary political-ideological (religious) tool without which policing - in Rancière's (2019:43-44) interpretation of police in opposition to politics - cannot function. The poor are necessary for any ideological (religious-ethical) system. Police (ideological and/or religious) systems cannot function without the poor, without victims - both the victims for whom they believe they fight and the victims the moral, social justice battles

5....the intellectual has causes other than justice to support: the earth, the land blood, race, freedom of thought, the proletariat, human rights, etc., these are the values which motivate, foremost, his action and give him the opportunity to values which motivate, foremost, his action and give him the opportunity to
practice. So that the intellectual depends always on values and causes the he defends as absolutes and that he refuses to question' (Laruelle 2015:55). 
create. For Rancière (2019), it is the need to move from ethics towards politics as a move that gives voice to the voiceless to give count to the unaccounted, but without these being identified within the parameters of a specific race, sex, culture or sexual orientation. That is the political move par excellence, but the poor cannot be equated with the people (demos) or the rabble in Ruda's sense, although poverty is a necessity for the emergence of the poverty rabble in contrast to the luxury rabble (see Ruda 2011:49ff.).

The world cannot be without the poor otherwise these systems (religious ethical - that is ideological) will not be able to exist, let alone flourish. The poor will indeed always be amongst one, but they are interpreted and ideologically 'used' very differently in the different ideological and religious systems. Thus, for example, one has the state church which has as one of its fundamental tasks to be the moral agent of the dominant ideology with a social conscience and therefore to 'care' for the poor through a social system. On the other hand, the prophetic church acts as ethical agent (in Levinas' sense) in believing themselves to be open to the other, and therefore speaking for or even believing themselves to be speaking with the poor: standing on the side of the 'oppressed' or standing (worshipping) in the porous spaces (Carvalhaes) or in the borderlands (Mignolo), often believing themselves to be the voice, or the space for the voice of the voiceless. But as Spivak (2010) had pointed out, the subaltern does not speak. When they do speak, they speak in the voice of some intellectual, ideological, philosophical and/or religious-ideological ethical voice (see Rancière ${ }^{6}$ 2019), in other words as a victimology (Laruelle 2015). This, for Rancière, is the task or even the essence of politics: 'The essence of politics consists in disturbing this arrangement by supplementing it with a part of those without part, identified with the whole of the community' (Rancière 2019:44). This understanding of politics should not be understood in a populist sense, but in a structural sense (Rancière 2019:41). Politics in a populist sense should then rather be understood as mega-politics (ideology). Megapolitics arises with the discomfort of the political subject between or in an interval or a gap (Rancière 1992:62). The point is that the oppressed (the poor) first need to be created as an identifiable entity to be able to stand on their side, to be able to take up their cause - the cause which first needs to have been identified or rather projected onto the poor as the people, thanks to certain intellectuals and/or philosophers:

\footnotetext{
... this stubborn insistence of 'making the mute speak', could we not always see on the horizon the figure of a single character: that unknown soldier whose habitual scene and occasional speech underpin the ability of political discourse to confer collective identities, giving history the weight of its acting subjects and reserving for philosophy the lightness of its thinking one? (Rancière 2011:10)
}

If one takes the above argument into consideration, one can at least identify two dominant kinds of liturgy within various societies:

6.'Politics exists insofar as the people is not identified with a race or a population, nor the poor with a particular disadvantage sector, nor the proletariat with a group of industrial workers, etc, but insofar as these later are identified with subjects that in inscribe, in the form of a supplement to vevery figure of the count of the uncounted or the part of those without part. That this part exits is the very stake of politics itself' (Rancière 2019:43).
1. Liturgy as moral agency of the dominant ideology, with the main function to form and shape good moral citizens: state church-state religion (theology) - state ideology.

2. Liturgy as prophetic agency, with the main function to believe to be giving voice to the voiceless and thereby to instil guilt in the dominant ideology and to present themselves as the true righteous voice of the slave: prophetic theology - 'revolutionary' ideology.

Both these two options continue to be a communicative presentation of the same world - a world where the poor will always be amongst one. This is a world in which the poor are at least twice exploited: firstly, economically, for example as cheap labour (slave labour), or whose land has been stolen, to increase profits; secondly, ideologically for ethical currency and political or politically correct profit. Very often that which is presented as post-colonial or decolonial liturgy falls into the temptation of such an exploitation of the poor for moral or ethical (politically correct or social justice) profit, all this to help in establishing who the righteous are in an evil and exploitative world. A pertinent question to ask in this imagined alternative world is as follows: Has the exploitation stopped, or has it shifted to another currency? The poor will always be amongst one as a structural necessity just as the divine is a structural necessity in the fourfold when worlds are spoken into being. These two necessities (God and the poor) are in a way linked, either as in the scapegoat mechanism, which functions for both the above liturgies, or as the God of the victim (see Girard 1987:154-168). The God of the victim or the God of the rabble needs to be explored to develop a non-colonial liturgy, but this God needs to be beyond good and evil.

\section{Beyond colonial and neo-colonial liturgies}

Is there a way beyond this binary of either moral or prophetic liturgy and the consequent constructive role of the two churches (state and prophetic) within the dominant worldview?

This article would like to suggest an exploration of the possibility of $a$ liturgy of the Real, as an alternative to the two options discussed above. A liturgy of the Real, a liturgy of the rabble, or a liturgy of the proletariat would be an alternative as it could be understood as a liturgy of love. 'The analyst loves by giving the gift of the gap to be suffered and enjoyed' (Tarpey 2011, [author's own emphasis]). A liturgy of the Real could be interpreted, and thus communicatively presented, as a non-colonial liturgy as it disrupts the colonial liturgies of both the state church and the neocolonial liturgies of the prophetic 'decolonial' church. In that sense, it would not be a police liturgy (in neither the state sense nor the prophetic sense), but a truly political liturgy.

If one compares the two churches of the Kairos Document to Deleuze and Guattari's (2011:11ff.) two sign regimes (despotic 
and prophetic), then these two together create the Abstract Machine that colonises the Body without Organs, which colonises the ethical space. The one (state church) tries to protect and guard the reifications of the layers of stratifications created, and the other seeks to create new stratifications for future exploitation or alternative exploitation, but all done in the good name of liberation and freedom (escape from the despotic god). These two together form the double pincer of the lobster God (Deleuze \& Guattari 2011:4) that colonised the earth by stratifying it into a world - with good and evil, rightand wrong, poor and rich, righteous and unrighteousness, voice and voiceless, and just and unjust.

Is there the possibility of another liturgy, another form of communicative presentation that does not call a world with various stratifications forth? Another liturgy that is not the moral agent of the dominant stratifications, nor the prophetic agent of those who claim to be just and righteous? A liturgy that presents a communication that is beyond good and evil? Or a liturgy that is prior to the determination of good and evil, a liturgy that finds itself within the matter of ethical space? A liturgy that is a speaking of language, but without that speaking calling a particular world into being, which would then have a very clear understanding of what the good is? In other words, a communication without presenting something, a communicative 'presenting' other than a communicative 'presentation' and a communicative 'presenting' that could be interpreted as a speaking cure, in the psychoanalytic sense. If it presents anything, it presents the gap, the cross of Christ and therefore love, or it is a communicative presenting of a communicative presentation (namely a pharmakon), and fully aware that what it is presenting is a pharmakon, thereby taking care of the pharmakon. A communicative 'presenting' that cares and nurtures the ethical space of universal production. ${ }^{7}$

A speaking (communicative presenting) that cares for the pharmakon (Stiegler 2013:77) as Bernard Stiegler argues. A speaking that takes care not of the Thing nor of the Lack, but of the pharmakon - in response to the matter of ethical space.

\section{Non-colonial liturgy amongst all the new developments in liturgical practices}

One is already in the midst of witnessing all sorts of new developments within the church concerning liturgy seeking to respond to that which Zygmunt Bauman has termed 'liquid modernity' (Bauman 2000). In the past, one could argue that various symbolic stratifications and reifications were replaced with a new stratification that was soon reified. Think of the replacement of the monarchy with for example Stalinism in the Soviet Union. So, in a sense one had the replacement of one solid with another solid, one reified stratum replacing another reified stratum. Bauman's argument is that in the contemporary world solids are no longer replacing solids, but there are flexibilisation (Bauman 2000:3)

\footnotetext{
7.In its process, universal production leads to ontological affirmations of the (fully indeterminate) nature of man which deploys the equality of anyone - the brotherhood of man - as a truth (Ruda 2011:174).
}

and liquidity, deregulation and liberalisation (see also Foley 2019:1- of 10). This development, if one can call it a development from solid to liquid, offers the church an opportunity to be less institutionalised according to Pete Ward (2002). Kees De Groot (2007:189) argues for a liquid koinonia, where churches are no longer these great institutions, but rather momentary types of community. These ideas that the world, specifically the Western world, have moved from solids to liquids have also had an impact on the study of rituals, with the phenomenon that has been named 'liquid ritualising' (see Arfman 2014). What Arfman (2014:23) is arguing is that rituals are no longer that solid and rigid but seem to adapt faster to the transformed context and are open to embrace and include elements from all sorts of traditions. This is not necessarily novel, as there has always been a ritual transfer between traditions, but what is new for Arfman (2014:4) is the overabundance of ritual transfer today.

Catherine Bell (1997) argued something similar, but decades earlier, with her interpretation of 'ritual invention'. Again, this was for Bell (1997:225) not a new phenomenon, but what is indeed new is the freedom with which people today invent and transform ancient rituals, while also incorporating elements from the vast spectrum of religious and nonreligious traditions. The question is if this is really a movement from solid to liquid? Or is it still a movement towards a new solid that happens to be liquid? In other words, the new norm, the new reified stratum, is this liquidity, and this liquidity is the new reified and stratified law of the age, with its normative character, and in this sense, liquidity is as solid and rigid as all the previous strata. It is the new norm, for example, if one takes what Foley is seeking when he turns to chaos theory to rethink God, not as an absolute stable and eternal solid substance or subject, but rather as an unpredictable uncertainty that is a source of tremendous potential and creativity:

In this metaphysic, God does not police the chaos, but witnesses to it, bringing the divine will to bear upon it when necessary, and employing it as a virtually limitless storehouse for creation. (Foley 2019:3 of 10)

The previous solid absolute eternal reified God has been replaced with an absolute eternal reified unpredictable creativity. In a sense, it is just a new name - a new master signifier - which is different to the previous master signifiers, but still a master signifier with which to explain all and dream and imagine an alternative better future.

\section{This allows him to argue that the:}

$[T]$ heologian's task, therefore, is to muse respectfully about this divine mystery - at least unpredictable if not chaotic from a human perspective - while still charting a path for responsible living and believing. (Foley 2019:3 of 10 [author's own emphasis])

Yet, does that really offer an alternative to move from a solid to a liquid interpretation of God, or to move from God of the Logos and stable structures and strata to the God of the tehom, for example? The same can be argued for Tillich's understanding of 'inexhaustible abundance' (see Foley 2019:3 of 10). Are these 
not two sides of the same coin, the coin of creation: tehom and Logos? It is Logos, the Word of God, that stratifies and etches into the Body without Organs (Deleuze \& Guattari 2011:4), or more specifically, in their words, it is the judgement of God that stratifies and thereby creates the strata. Thus, they interpret God as a lobster God. 'God is a Lobster, or a double pincer, a double bind. Not only do strata come at least in pairs, but in a different way each stratum is double (it itself has several layers)' (Deleuze \& Guattari 2011:4). The double pincer - is it not the tehom and Logos that together create the strata of the world one lives in?

Does it really matter if one focuses on God as Logos or on God as tehom? The one (tehom) is created to receive the etchings and the carvings of the other (Logos). Or it is the old battle between Dionysus and Apollo - who need each other to exist. One could also argue for a dialectic and for Victor Turner's (1969) understanding of liminality and communitas as a time of being betwixed and between. If one interprets Turner's liminality within the context of the move towards interpreting God within the metaphors of chaos theory, one could say that one finds oneself in a liminal space that forms part of a dialectical movement from structure (Logos) and then un-structure (tehom) before re-establishing structure. And as Foley says, the 'path of responsible living and believing' is according to the new norm.

To place this argument into Lacanian (Lacan 1999:123ff) terms, one could argue that for years liturgies and being church have focused on the imaginative and symbolic realms of the Borromean knot. This turn towards chaos theory could be interpreted as a believed turn towards the Real. However, that is not really a possibility, as was argued in [Call]Responding (Meylahn 2021), as the Real only exists as that which is believed to have called the response forth, but in the response. Therefore, it is not a matter of choosing one of these realms - Real, Symbolic or Imagination - but understanding how these three together form the knot in which humanity becomes a subject - a barred subject.

It is this understanding, this pharmacological understanding, that makes something new possible, without choosing one or the other of the three realms, the understanding that it is only in the web of this knot that it is possible to be, and that by understanding the different functions of the three realms, that one can seek to live creatively within this knot and more specifically with the knot by taking care of the knot - rather than the eternal attempts at trying to untie the knot or escape the knot. Any attempt at escape would only be recaptured, as one cannot escape the rhizome, or any attempted escape would only be possible in the realm of the imagination and the structuring of a new symbolic world in response to one's believed Truth about the Real. The alternative, if one wants to call it an alternative, is not to seek to escape the knot, but to learn to live creatively and productively within the knot (Stiegler's care for the pharmakon). However, loosening the knot so as to not be duped, most importantly not to be duped by believing oneself not duped (see Meylahn 2021:134; Žižek 2012:971).
What does all this mean for liturgy and specifically noncolonial liturgy? The knot in the power of the symbolic or in the power of the imagination or in the power of the believed Real is colonial. The knot is colonial as is Deleuze and Guattari's lobster God that holds one in a double bind or a triple bind. Therefore, a non-colonial liturgy would be a liturgy that is fully aware of the functioning of the lobster God and the triple bind or triple curse (Meylahn 2021:88). Likewise, being fully aware that one cannot escape and that any attempt at an escape would only be a renaming of the same lobster God. There is the possibility of a certain Gelassenheit, but Gelassenheit might play too easily into the clutches of the dominant ideology. The other alternative is to deconstruct, But deconstruction often happens in the righteous belief in freedom and the possibility of entering the promised land on the other side of deconstruction towards the eternal ethical call of the Other. One could consider deconstruction in radical freedom without the belief in the promised land, freedom to view the current land through the eyes of freedom (care of the pharmakon) and therein maybe see new pharmacological possibilities - universal production. To believe in the world (Stiegler 2013:111) as world and not as earth. Thus, the purpose of a non-colonial liturgy would primarily be deconstruction of the various lobster Gods, not in the name of some or other good - nor in the name of a meta-lobster God, but in the name of faith in the pharmakon: the crucified and resurrected Christ.

The non-colonial liturgy would take care of the Christ Event, as it would take care of the pharmakon: the death of God in the incarnation and the death of the incarnation on the cross and the resurrection life that this death makes possible - a life of radical freedom, as Luther argues, ${ }^{8}$ namely a slave to nothing and yet a slave to all, thereby exposing the systems that will always have their poor, and bringing about the possibility of change that even changes the laws of change.

\section{How does this translate into a communicative presenting of a Sunday liturgy?}

How does one offer a non-colonial liturgy? How does one deconstruct in a Sunday service without the hope and faith in a promised land behind the deconstruction? Hope and faith in the life thereafter will indeed be there, but it is hope and faith placed in the pharmacological life (resurrection life) and not some imagined or symbolically structured police life thereafter nor the lack or nothing of no life thereafter. In practical terms, it is therefore not about privileging the colonial patriarchal heterosexual male priest's voice nor about privileging the border, migrant or indigenous voice, but about privileging the count of the uncounted, by privileging, if one wants to privilege anything, the call of the ethical space: democracy and the radical equality of all voices, that does not give any voice in particular the right to be

8.'Ein Christenmensch ist ein freier Herr über alle Dinge und niemand untertan; Ein Christenmensch ist ein dienstbarer Knecht alle Dinge und jedermann untertan' Christenmensch ist ein dienstbarer Knecht alle Dinge und jedermann untertan
(https://www.luther2017.de/martin-luther/texte-quellen/lutherschrift-von-derfreiheit-eines-christenmenschen/index.html) 
heard. In this radical democracy - the voices are what they are, namely equal - equally qualified and equally disqualified.

To help one to seek a non-colonial liturgy, I will turn to Wilhelm Gräb's (2013) book on religious speech, where he argues that preaching should be religious speech and I will argue that non-colonial preaching (liturgy) needs to be nonreligious speech. For it to be non-religious in the sense of Laruelle's (2013) non-philosophy, it is not against religion nor is it after religion as in some post-religion sense, but it is maybe like Heidegger's verwundung of metaphysics (see Meylahn 2013:18ff.). Discovering the wound in religion, the wound in metaphysics, the wound in ideology and the wound in colonial thinking. The immortal wound that cannot be healed, which is the wound both at the heart of religion, ideology, colonial thinking (the judgement of God) as well as the eternal wound to which religion, ideology, colonial thinking, passionately responds in the hope of being the eternal cure to the immortal wound, and thus making all voices, all speaking equal and democratic as they are all a response to this wound which is caused by the response.

In this sense, Gräb (2013) is correct by arguing that in the crafting of a divine service one needs to turn towards religion, not to seek the religious needs and desires of the context, but to seek the wound in religion, ideology and the wound at the heart of colonial thinking and being - the wound at the heart of speaking. To seek the judgement of God, which in an ironical sense sounds very close to the traditional interpretation of a typical protestant service: the idea of proclaiming the law (judgement of God) so as to entice the listener towards the Grace of Christ. To seek the wound in religion, to seek the judgement of God, is not to instil guilt in the listener who then flees towards the Grace of Christ, but to seek the wound in thinking (speaking), to seek the judgement of God indeed takes one to the Cross of Christ. In the Cross of Christ, in Christ's utter Godforsakenness, one is radically and impossibly free from the judgements of God who has forsaken Christ. To have no imagined or symbolic support, but to find oneself in the lack, in the nothing, and there discover that the wound caused by the spear (pharmakon), as in Wagner's Parsifal, can also only be healed by the exact same spear (pharmakon). The healed life (the resurrection life), wounded and healed by the same spear (pharmakon), is a life that recognises and acknowledges the pharmacological nature of life and takes care of this life.

What does this mean concretely with regard to crafting a service?

It means that the judgements of God need to be exposed (the judgements of God in ideology, religion, colonial and neocolonial thinking of many decolonial schools of thought). The judgement of God in any speech needs to be exposed. They are exposed not by another meta-judgement of God but by the wound that calls these judgements forth in response to a perceived wound and where all these different judgements are presented as healing, salvation, justice, wholeness and holiness (righteousness).
The wound that calls and the wound that responds, like an abyss calling to an abyss, need to be recognised. In this calling-responding, one must recognise that the wound and the weapon that caused the wound are the same; that is, it is also the healing of the wound.

The pharmakon is worth caring for, as it is resurrection life life that recognises its pharmacological 'nature'.

Such a liturgy might be political where the world is not policed, but called forth by a political act - the speaking of all beings (universal production) in a radical democracy of the indeterminate ethical space - where the right to rule and the right to be heard have been equalised.

\section{Acknowledgements Competing interests}

The author declares that he has no financial or personal relationships that may have inappropriately influenced him in writing this article.

\section{Author's contributions}

J-A.M. is the sole author of this article.

\section{Ethical considerations}

This article followed all ethical standards for research without direct contact with human or animal subjects.

\section{Funding information}

This research received no specific grant from any funding agency in the public, commercial or not-for-profit sectors.

\section{Data availability}

Data sharing is not applicable to this article as no new data were created or analysed in this study.

\section{Disclaimer}

The views and opinions expressed in this article are those of the author and do not necessarily reflect the official policy or position of any affiliated agency of the author and the publisher(s).

\section{References}

Arfman, W., 2014, 'Liquid ritualizing: Facing the challenges of late modernity in an emerging ritual field', Journal of Religion in Europe 7(1), 1-25. https://doi. org/10.1163/18748929-00701001

Bauman, Z., 2000, Liquid modernity, Polity, Cambridge.

Bell, C., 1997, Ritual: Perspectives and dimensions, Oxford University Press, New York, NY.

Carvalhaes, C. (ed.), 2015, 'Liturgy and Postcolonialism: An introduction', in C. Carvalhaes (ed.), Liturgy in postcolonial perspectives: Only one is holy, pp. 1-20, Palgrave Macmillan, London.

De Groot, K., 2007, 'Rethinking church in liquid modernity', in H. Streib (ed.), Religion inside and outside traditional institutions, pp. 175-191, Brill, Leiden.

Deleuze, G. \& Guattari, F., 2011, A thousand plateaus: Capitalism and schizophrenia, transl. B. Massumi, University of Minnesota Press, Minneapolis, MN.

Foley, E., 2019, 'Sacramentality, chaos theory and decoloniality', Religions 10(7), 418. 
Freud, S., 1964, 'New introductory lectures on psychoanalysis (1932-1936)', in Complete works, standard edition, Vol XXII, transl. J. Strachey, pp. 158-184, The Hogarth Press and the Institute of Psycho-analysis, London.

Girard, R., 1987, Job the victim of his people, transl. Y. Freccero, The Athlone Press, London.

Gräb, W., 2013, Predigtlehre: Über religiöse Rede, Vandenhoeck \& Ruprecht, Göttingen.

Grosfoguel, R., 2009, 'A decolonial approach to political-economy: Transmodernity, border thinking and global coloniality', in J. Suárez-Krabbe (ed.), Kult 6 - Special issue epistemologies of transformation: The Latin American decolonial option and its ramifications, pp. 10-38, Department of Culture and Identity, Roskilde.

Heidegger, M., 1971, Poetry, language, thought, transl. A. Hofstadter, Harper \& Row, New York, NY.

Kee, A., 1990, Marx and the failure of liberation theology, SCM Press, London.

Lacan, J., 1999, Encore, the seminar of Jacques Lacan Book XX: One feminine sexuality, the limits of love and knowledge. 1972-1973, transl. B. Fink, W.W. Norton, New York, NY.

Laruelle, F., 2013, Principles of non-philosophy, transl. N. Rubczak \& A.P. Smith, Kindle version, Bloomsbury, London.

Laruelle, F., 2015, Intellectuals and power: The insurrection of the victim - François Laruelle in conversation with Philippe Petit, transl. A.P. Smith, Polity, Cambridge.

Lynch, T., 2014, 'Making the quarter turn: Liberation theology after Lacan', in C. Davis, M. Pound \& C. Crockett (eds.), Theology after Lacan: The passion for the real, pp. 211-231, Cascade Books, Eugene, OR.

Meyer-Blanck, M., 2015, 'Die christliche Liturgie als Moralagentur der Gesellschaft', Paper presented at XVII. Konsultation Kirchenleitung und wissenschaftliche Theologie, Eisenach, 17 September 2015.

Meylahn, J.-A., 2013, The limits and possibilities of postmetaphysical God-talk: A conversation between Heidegger, Levinas and Derrida, Peeters, Leuven.

Meylahn, J.-A., 2021, [Call] - Responding and the worlds in between: Doing (non) philosophy in a time of democratic materialism, Lit Verlag, Wien.

Mignolo, W., 2011, The darker side of western modernity, Duke University Press, Durham, NC.

Munn, N.D., 1973, 'Symbolism in a ritual context', in J.J. Honigmann (ed.), Handbook of social and cultural anthropology, pp. 579-612, Rand McNally, Chicago, IL.
Rancière, J., 1992, 'Politics, identification, and subjectivization', in October, Vol. 61, The identity in question, pp. 58-64, The MIT Press, New York.

Rancière, J., 2003, The philosopher and his poor, transl. J. Drury, C. Oster \& A. Parker, Duke University Press, Durham, NC.

Rancière, J., 2011, Staging the people: The proletarian and his double, transl. D. Fernbach, Verso, London.

Rancière, J., 2019, Dissensus: On politics and aesthetics, ed. and transl. S. Corcoran, Bloomsbury Academic, London.

Ruda, F., 2011, Hegel' Rabble: An investigation into Hegel's philosophy of right, Continuum, London.

Schleiermacher, F.D.E., 1850 (1983), Die Praktische Theologie nach den Grundsätzen der evangelischen Kirche in Zusammenhange dargestellt, Hg. v. J. Friedrichs, De Gruyter, Berlin.

Spivak, G.C., 2010, 'Can the subaltern speak?', in R. Morris (ed.) Can the subaltern speak?:Reflections on the history of an idea, pp. 66-111, Columbia University Press, New York, NY.

Stiegler, B., 2013, What makes life worth living: On pharmacology, transl. D. Ross, Polity Press, Cambridge.

Tarpey, G., 2011, Lacan's psychoanalytic way of love, psychoanalysislacan.com, viewed 15 November 2020, from http://psychoanalysislacan.com/wp-content/ uploads/2015/11/Alves_Tarpie_Lacans_Psychoanalytic_Way_Love.pdf.

The Kairos Theologians, 1985, Challenge to the church, Kairos document, a theological comment on the political crisis in South Africa, pp. 1-36, viewed 30 November 2020, from http://ujamaa.ukzn.ac.za/Libraries/manuals/The_Kairos_Documents. sflb.ashx.

Turner, V., 1969, 'Liminality and communitas', in B.V. Turner, R.D. Abrahams \& A. Harris (eds.), The ritual process: Structure and anti-structure, pp. 94-113, 125-130, Aldine Publishing, Chicago, IL.

Ward, P., 2002, Liquid church, Henrickson, Peabody, MA.

Wyller, T., 2018, 'Decolonial counter-conducts? Traces of decentering migrant ecclesiologies', Alternation Special Edition 22, 142-158. https://doi. org/10.29086/2519-5476/2018/sp22a8

Žižek, S., 2012, Less than nothing: Hegel and the shadow of dialectical materialism, Verso, New York, NY. 